\title{
Social Unionism, Public Relations, and Support for Unions: A Case Study of Public Opinion in Saskatchewan, Canada
}

\author{
David McGrane, St. Thomas Moore College, University of Saskatchewan, Canada \\ Loleen Berdabl, University of Saskatchewan, Canada
}

\begin{abstract}
Academic research on public attitudes towards unions in Canadian provinces is virtually nonexistent. Using quantitative evidence from a Saskatchewan telephone survey, we demonstrate that public attitudes towards unions are more positive when the labour movement is perceived to be working for the betterment of all society and more negative when unions are perceived to be pursuing the narrow interests of their own members. Surprisingly, even though residents who are outside of the workforce receive no direct benefits from unions, they display more supportive attitudes toward unions than the employed. Two implications for the concept of Canadian social unionism flow from these findings. First, to the extent that Canadian social unionism stipulates that union activity benefits all of society, it is a good public relations strategy. Second, Canadian social unionism can become a way for the labour movement to appeal to the non-employed (retirees, students, full-time caregivers, and the unemployed) who are predisposed to be supportive of union struggles.
\end{abstract}

\section{KEYWORDS}

Canada; public opinion; public relations; Saskatchewan; social unionism.

Canadian labour unions are currently under considerable pressure. Unionization rates are declining, organized labour is being increasingly concentrated in the public sector, and the growing numbers of service sector employees have proven notoriously difficult to organize (Morisette et al., 2005: 6; Schmitt and Mitukiewicz, 2012; Uppal, 2010: 21; Visser and Checchi, 2009). At the same time, both the federal government and provincial governments in Canada have embarked on 'austerity bargaining' with public sector workers and are making various legislative changes that unions perceive to be unfriendly to their interests. Public opinion can be expected to play a role in the upcoming clashes between unions, governments, and business, with each of these groups attempting to sway public opinion towards their way of thinking. The success or failure of each group's efforts to garner public support could prove pivotal for the future of labour relations.

Despite the importance of public opinion to understanding labour relations, there has been very little research done on public attitudes towards unions in North America and no research has appeared on public opinion towards unions in Canadian provinces. This article begins to fill this gap in our knowledge by exploring the public attitudes towards labour unions using the case of Saskatchewan, Canada. Specifically, we analyze an original survey dataset, the 2011 Saskatchewan Election Study (SKES), to answer three research questions: 
1. How does the public feel about unions?

2. What is the socio-demographic profile of supporters and opponents of unions?

3. What are the public relations implications of these findings for unions, the business community, and governments?

Saskatchewan is an interesting case study for a number of reasons. The province has relatively strong unionization rates: $33.8 \%$ of the total workforce in 2010 was unionized, making Saskatchewan Canada's fourth most unionized province, following Newfoundland and Labrador, Quebec and Manitoba (Uppal, 2010: 18). Moreover, for decades unions have enjoyed considerable political relevance in provincial politics. The social democratic Co-operative Commonwealth Federation (CCF) and its successor the New Democratic Party (NDP) held power $70 \%$ of the time between 1944 and 2010, with part of the CCF/NDP success owing to the support of unions. However, while Saskatchewan 'is widely viewed as the cradle of Canadian social democracy' (Wesley, 2011: 1), the pro-business and conservative Saskatchewan Party won a second mandate in a landslide victory in the 2011 provincial election despite passing a number of laws that were criticized by the province's labour movement as being 'anti-union'. The extent to which favourable attitudes towards unions in a historically 'left-wing' and 'pro-union' province have eroded may have important lessons for all jurisdictions where conservative governments are bargaining hard with public sector unions and introducing labour legislation that runs counters to the labour movement's interests.

In this article, we demonstrate that public support for unions is nuanced. In so far as the public perceives unions as narrowly defending the interests of their own members, the public reaction is negative. However, public opinion is more positive if unions are perceived as working to better all of society. As one might expect, support for unions is highest among union members, those living in union households, NDP partisans, and (to a lesser extent) the well educated. Quite surprisingly, support for unions is stronger among the non-employed such as retirees, full-time students, and the unemployed than it is among the employed. The support of unions by those outside of the workforce may be predicated on these citizens seeing unions as fighting for adequate government programs to aid the economically insecure.

These findings have two important public relations implications for Canadian social unionism. First, Canadian social unionism's idea of union activity as benefitting all of society appears to be a good public relations strategy. Public opinion may be more open to supporting unions when it receives the message that unions work for all of society and not just for union members. As such, social unionism in Canada should not only be seen as an imperative for social justice or a means to renewing the union movement. One of the benefits of Canadian social unionism that has been underappreciated is that it is an effective method for gaining public support for union demands. In contrast, our analysis suggests that Canadian businesses and governments that are negotiating with unions would be well-advised to portray unions as 'special interest groups' concerned exclusively about defending the interests of members. Unless unions can create an alternative image, public relations campaigns focused on how unions are simply 'asking for too much' are likely to be successful. Second, while unions would be wise to continue to attempt to create forms of solidarity with non-unionized workers, the analysis suggests that unions should also be aware that they have potential allies among those who are outside of the workforce who should not be neglected. Canadian social unionism's insistence on building coalitions with the broader community outside of the labour movement makes it particularly adept at taking advantage of this opportunity. Framing union demands in ways that appeal to social groups outside of the workforce could be a fruitful 
strategy to creating a more favourable public relations environment for unions when faced with conservative governments dedicated to undermining their historic gains.

\section{Canadian Social Unionism and Public Relations}

Social unionism is generally considered to be the dominant form of unionism within Canada (Savage and Soron, 2011: 38). The ethos of Canadian social unionism is that unions must look beyond the economic interests of their members and work for the good of the entire community of which they are a part (Kampur and Murray, 2006; Robinson, 1993; Ross, 2007, 2012). In addition to securing better benefits and higher wages through collective bargaining, unions must be concerned with issues that affect their community and their members' lives outside of the workplace. Indeed, the interests of union members (for example, having adequate unemployment insurance, good social programs, a clean environment) intersect with the well being of their community as a whole. This ethos is operationalized by long-term affiliations with social democratic parties, the mobilizing of members to lobby governments on issues that fall outside of the bounds of collective bargaining, the building of alliances with community-based groups outside of the labour movement, and substantial contributions to charitable work.

It should be noted that there is debate among labour scholars concerning the exact definition of Canadian social unionism and how the concept plays out in practice. Indeed, scholars note that Canadian unions are often 'complex hybrids' of several different models of unionism (Ross, 2007: 22). For instance, Ross (2008) argues that Canadian social unionism generally encourages the mass participation of members within internal decision-making, but not all social unionist strategies in Canada have pursued such a participatory framework. Similarly, Ross (2011) and Hrynyshyn and Ross (2010) have critiqued how the Canadian Autoworkers' use of non-adversarial discourses and strict avoidance of appearing to be anti-business belies their claim to practice social unionism. Savage and Soron (2011) explore how the Canadian Labour Congress' hesitancy to endorse nuclear power is founded on the social unionist principle of seeking what is best for the entire community but that its ability to work with anti-nuclear groups outside of the labour movement has been hampered by militant pro-nuclear activists within its ranks. Canadian unions' long-term affiliation with the social democratic NDP has also been a topic of intense debate. Several scholars have questioned the NDP's willingness and ability to combat the neo-liberal restructuring of the Canadian economy and have called for unions to look beyond electoral considerations if they are really interested in building political power for workers (Albo, 2002; Smith, 2011; Evans, 2012; Savage, 2012). Others have stressed how the NDP has remained true to its social democratic principles and have outlined the mutually beneficial relationship between the NDP and Canadian unions (Jensen and Young, 2009; Laycock, 2014; McGrane, 2014).

Labour scholars outside of Canada grapple with similar issues. While Canadian scholars have focused on the concept of 'social unionism', international scholars have created a variety of different models of unionism to capture the complex array of union practices around the globe. Social movement unionism (SMU) has proved to one of the more popular conceptual models. The conceptual framework of SMU originated out of innovative union organizing practices in countries within the Global South such as South Africa, Brazil, Philippines, and South Korea and was later applied to Northern countries like the United States (Moody, 1997; Webster, 2008; Celik, 2014). While there are disagreements about the definition of SMU (see Seidman, 2011), Robinson identifies the core of the concept as being that unions understand themselves as 'part of a larger

social movement that aims to bring the economic and political order into line with the ideals and possibilities identified by their notion of a just political economy' (2000: 113). SMU advocates 
building coalitions with non-union members; pursuing electoral politics and collective bargaining alongside more unconventional forms of protest; having participatory and democratic internal union structures; and advocating for issues of concern to the entire community as opposed to concentrating solely on the interests of union members (Robinson, 2000; Webster, 2008; Suzuki, 2012). The extent to which unions practicing social movement unionism should be integrated into political parties remains a subject of debate. For instance, Pillay (2013) has recently argued that the Congress of South African Trade Unions moved away from social movement unionism into 'political unionism' when it aligned itself closely with the governing African National Congress. Webster (2008) reminds researchers that it is unwise to transfer union models across time and space and discount the importance of national union traditions. Therefore, it would be a mistake to conflate SMU with Canadian social unionism. However, it is interesting that international scholars of SMU and scholars of Canadian social unionism are struggling to understand similar phenomena and issues. As such, debates on Canadian social unionism may have pertinence for analysts researching SMU and other union models elsewhere in the world.

Within the conceptualization of Canadian social unionism, the role of public relations and public opinion has been underappreciated. Canadian social unionism is generally presented as a method for union revitalization or an imperative of social justice. However, the connection between public relations and Canadian social unionism has not been explored. Both social movement literature and business management literature have long recognized the importance of public relations. Research on social movements has built up various conceptual approaches to describe the process of framing issues to shape public opinion and to attract new adherents to movements (Benford and Snow, 2000). Likewise, intensive research on the practice of public relations within business organizations can be found in publications such as the Journal of Public Relations.

Additionally, there has also been very little academic research done on Canadian public attitudes towards unions. The available research indicates that, as might be expected, union membership influences individuals' attitudes towards unions (Bibby, 2002; Canadian Labour Congress, 2003; Krahn and Lowe, 1984; Leger Marketing, 2003). So, as unionization rates have declined, so too has public support for unions (Bibby, 2002; Environics Institute, 2011; Leger Marketing, 2003) and support for unions' right to strike (Angus Reid Strategies, 2007, 2008). However, existing public opinion research only gives us an understanding of the general support for unions in Canada. There has been limited use of questions that could discern the nuances of public opinion toward unions or provide useful data to evaluate the public relations strategies of the labour movement.

It is also important to note that the above research has been done on the national scale and there is no research on the public opinion towards unions within individual Canadian provinces. In Canada, provincial governments have constitutional jurisdiction over approximately $90 \%$ of workers while the federal government regulates only those workers in the federal public service and a handful of 'national' industries such as banks, railways, and telecommunications (Swimmer and Bartkiw, 2006). As such, most of the heated battles over labour legislation and public sector bargaining in Canada take place at the provincial level and it is therefore important to gain an understanding of public opinion toward unions within Canadian provinces.

An appreciation of the public relations challenges for unions begins with an understanding of public attitudes and the critical role that 'framing' plays in public relations. For Entman (1993), framing within public relations involves selecting 'some aspects of perceived reality and making them more salient in the communicating text, in such a way as to promote a particular problem definition, causal interpretation, moral evaluation and/or treatment recommendation for the item described.' Hallahan (1999) describes how, within the realm of public relations, issues can be explained in 
alternative terms by different parties who vie for their preferred definition of a problem or situation to prevail.

Public relations and framing are becoming increasingly important parts of union activity. In the context of negotiations and strike activity, public sector unions are continually involved in a public relations battle against governments. Further, the public relations activities of unions are an important way in which opposition is mobilized against legislation that unions perceive to be detrimental to their interests. With businesses becoming increasingly conscious of their image, public relations can also play a role in relations between unions and private sector employers. This is not to say that better public relations alone can somehow alter the fundamental power imbalance between capital and labour. However, good public relations strategies can be part of the broader social engagement used by unions to advance progress on their concerns and demands. Public relations should therefore be considered as an important tool in any union's toolbox. Further, it is our view that debates around the concept of Canadian social unionism among academics would benefit greatly from an understanding of public opinion towards unions and a greater focus on public relations. After the next section describing the political situation of the labour movement in Saskatchewan, a quantitative research design is introduced to evaluate the structure of public opinion towards unions in Saskatchewan.

\section{Unions, Labour Legislation, and Saskatchewan Politics}

Unions and issues surrounding labour legislation have played a historically important role in Saskatchewan politics. One of the founding partners in the creation of the social democratic Cooperative Commonwealth Federation (CCF) in 1932 was the Independent Labour Party of Saskatchewan and labour activists constituted an important part of the new party's activist base. While the Saskatchewan branch of the CCF was only officially affiliated with a small number of union locals in the province, the Canadian Congress of Labour formally endorsed the national CCF as its political arm during the late 1930s (Lindsay, 1987). The CCF won a landslide victory in the 1944 Saskatchewan provincial election and is generally recognized as the first social democratic government in North America (Lipset, 1950). Since the CCF's historic victory, labour legislation in Saskatchewan has been a partisan battleground swinging between pro-business and pro-union amendments as governments have changed.

One of the first moves by the CCF upon its election was to pass several pieces of groundbreaking labour legislation that made Saskatchewan the most union-friendly jurisdiction in North America (Smith, 2011). For instance, the approval threshold for a union certification vote was set at $25 \%$, public sector workers were given the right to unionize, and unions were allowed to strike during the life of a collective agreement. The Saskatchewan CCF did not lose power until 1964, after which it changed its name to the NDP and formally affiliated with the union movement as part of a Canada-wide initiative to create a labour party that was connected to the newly formed Canadian Labour Congress. During the 1960s, the Liberal provincial government in Saskatchewan infuriated unions and the NDP opposition by significantly revising the Trade Union Act in the employer's favour and introducing the Essential Services Emergency bill that gave cabinet the power to end strikes by either imposing compulsory arbitration and or decertifying the union if cabinet felt the union had not made a sufficient effort to reach an agreement (Archer, 1980: 321).

When it returned to power in 1971, the NDP faced down opposition from the Liberals and Saskatchewan business to implement a large number of amendments to labour legislation that favoured unions such as giving construction workers the right to sectorally bargain, reducing the 
work week to 40 hours, and allowing employees the right to refuse what they believed to be unusually dangerous work (Snyder, 1997). Subsequently, in the face of opposition from the NDP and unions, these reforms were undone by the Progressive Conservative government during the 1980s as legislative changes made it easier for management to designate workers as out of scope, unions were not allowed to discipline their members for crossing picket lines, and a vote on the employer's final offer after 30 days of striking became mandatory (McCuaig et al., 1991). From 1991 to 2007, the NDP government then made a number of controversial changes to labour legislation that raised labour standards and made it easier to organize new unions, such as requiring that companies with at least ten employees pay pro-rated full time benefits to their part-time employees, requiring that state-owned companies hire contractors who use union labour and pay union wages, and removing references to the employers' right to 'free speech' during certification drives and strikes (McGrane, 2008: 148-149; Warren and Carlisle, 2005).

The most recent political developments in Saskatchewan have repeated this familiar pattern. In 2007, the pro-business Saskatchewan Party won the provincial election. Early in its mandate, the Saskatchewan Party enacted laws that placed limits on public sector strikes, changed the rules for the establishment of unions, and eliminated sectorial bargaining in the construction industry (Smith, 2011: 143). Unions, the Saskatchewan Federation of Labour, and the Saskatchewan NDP voiced strong opposition, arguing that these laws violated the rights of unionized workers, and several unions challenged the constitutionality of the changes in Canadian courts, arguing that the laws were a violation of the Charter of Rights and Freedom's right to freedom of association. As a result of the court challenge, the essential services law was struck down.

Overall, Saskatchewan makes an interesting case for the study of public relations and public attitudes towards unions. Unlike elsewhere in Canada, union density in Saskatchewan has remained relatively stable over the last thirty years (Smith, 2011: 129). Further, Saskatchewan has a history of an electorally successful social democratic party that is supported by a politically active labour movement and has a record of enacting union-friendly labour legislation. As such, one may expect to find a high level of pro-union attitudes amongst the Saskatchewan public. On the other hand, despite passing several pieces of labour legislation that were decried as unfair by unions, the Saskatchewan Party won an unprecedented 64\% of the popular vote in the 2011 provincial election. If favourable attitudes towards unions are flagging in the province with the rise of the electorally successful Saskatchewan Party, it bodes poorly for union attitudes in other jurisdictions where conservative, pro-business parties govern. Indeed, Saskatchewan may hold public relations lessons for other jurisdictions where conservative governments are pushing through controversial labour legislation or are engaging in austerity bargaining with public sector unions.

\section{Findings: The Nuanced Attitudes towards Unions in Saskatchewan}

The Saskatchewan Election Study (SKES) is a post-election general population telephone survey of 1,099 Saskatchewan residents (see Methodological Appendix). The survey included three questions that were designed to delve deeper into public attitudes towards unions than previous research. First, respondents were asked to rate their agreement with the statement, 'All things considered, unions in Saskatchewan generally ask for too much.' Second, participants were asked to rate their agreement with the statement, 'Strong unions are needed to protect employees' working conditions and wages.' And third, respondents were asked, "When you hear of a strike, are your sympathies typically 'Always for the Union', 'Usually for the Union', 'Usually Against the Union', or 'Always Against the Union'?" 
Basic frequencies are presented in Table 1. The data suggest that a sizeable proportion of the Saskatchewan public (over one-quarter of respondents) strongly agrees that unions ask for too much, while another three in ten somewhat agrees with this statement. In total, almost three in five respondents believe that union demands can be excessive. Such attitudes suggest that if the labour movement's positions can be successfully portrayed as merely promoting the interests of its members, public sympathy will lie with union critics.

Sentiments become more favourable to labour unions when the focus shifts from union 'demands' to union 'activities'. Over one-quarter of respondents strongly agree and almost four in ten respondents somewhat agree that unions are necessary to protect employees' interests and wages. The strong majority (almost two-thirds) of Saskatchewan residents can thus be seen as being 'supportive' of the role that unions play in protecting the well being of workers in their community.

The final question, which explores predispositions towards strikes, suggests that Saskatchewan residents are neither entirely 'for' nor 'against' unions exercising their power to strike. While almost one in ten reports 'always' being unsympathetic and one in twenty reports 'always' being sympathetic to striking unions, over $70 \%$ of respondents chose the more cautious 'usually against' or 'usually for' options. This result suggests that public attitudes toward labour union strikes may vary on a case-by-case basis.

Table 1: Public Attitudes toward Unions in Saskatchewan, 2011

\begin{tabular}{|c|c|c|c|c|c|}
\hline Question & $\begin{array}{l}\text { Least } \\
\text { Supportive } \\
\text { Attitudes }\end{array}$ & $\begin{array}{c}\text { Less } \\
\text { Supportive } \\
\text { Attitudes }\end{array}$ & $\begin{array}{c}\text { More } \\
\text { Supportive } \\
\text { Attitudes }\end{array}$ & $\begin{array}{c}\text { Most } \\
\text { Supportive } \\
\text { Attitudes }\end{array}$ & $\begin{array}{c}\text { Don't } \\
\text { Know/ } \\
\text { Refused }\end{array}$ \\
\hline $\begin{array}{l}\text { Unions ask for } \\
\text { too much }\end{array}$ & $\begin{array}{l}26.3 \% \\
\text { strongly } \\
\text { agree }\end{array}$ & $\begin{array}{c}31.8 \% \\
\text { somewhat } \\
\text { agree }\end{array}$ & $\begin{array}{c}20.0 \% \\
\text { somewhat } \\
\text { disagree }\end{array}$ & $\begin{array}{c}14.2 \% \\
\text { strongly } \\
\text { disagree }\end{array}$ & $7.7 \%$ \\
\hline $\begin{array}{l}\text { Unions needed } \\
\text { to protect } \\
\text { employees }\end{array}$ & $\begin{array}{c}12.1 \% \\
\text { strongly } \\
\text { disagree }\end{array}$ & $\begin{array}{c}19.7 \% \\
\text { somewhat } \\
\text { disagree }\end{array}$ & $\begin{array}{c}38.0 \% \\
\text { somewhat } \\
\text { agree }\end{array}$ & $\begin{array}{l}26.8 \% \\
\text { strongly } \\
\text { agree }\end{array}$ & $3.3 \%$ \\
\hline $\begin{array}{l}\text { Sympathies } \\
\text { during strike }\end{array}$ & $\begin{array}{c}7.6 \% \\
\text { always } \\
\text { against union }\end{array}$ & $\begin{array}{c}36.2 \% \\
\text { usually } \\
\text { against the union }\end{array}$ & $\begin{array}{c}36.1 \% \\
\text { usually } \\
\text { for the union }\end{array}$ & $\begin{array}{c}4.7 \% \\
\text { always } \\
\text { with the union }\end{array}$ & $15.6 \%$ \\
\hline
\end{tabular}

Source: Saskatchewan Election Study (2011)

Previous research in Canada and the United States suggests that support for unions varies amongst socio-demographic groups; in particular, and as stands to reason, union members and nonunion members have been found to differ significantly (Bibby, 2002; Freeman and Medoff, 1984; Jones, 2010; Krahn and Lowe, 1984; Pew Research Center, 2010; Saad, 2009), and partisanship often structures attitudes towards unions (Angus Reid Strategies, 2007; Environics Institute, 2011: 22; Jones, 2010; Pew Research Center, 2010). In this case, partisanship means self-identifying with a political party - for example, as 'Liberal', 'New Democrat' or 'Conservative' - which is a deeper commitment to the party than just voting for it. North American research also suggests that age, education, income and gender differences can be found in attitudes towards unions (Angus Reid Strategies 2007, 2008; Bibby, 2002: 2; Freeman and Moser, 2010).

To examine such socio-demographic variations in Saskatchewan attitudes towards unions, multivariate analyses were performed separately on each of the questions outlined above. Additionally, the three survey questions were combined to create a single 'support for unions index' 
ranging from 1.0 ('anti-union' attitudes) to 4.0 ('pro-union' attitudes) (see methodological appendix for details on the index and the socio-demographic variables). The use of an index implies that one of the key concepts that we are investigating, which is general support for unions, is additive and structured like a continuum. The higher a respondent's score on the index the more likely that s/he is to be 'pro-union' and the lower the respondent's score the more likely that $s /$ he is to be 'antiunion.' When it comes to their overall support for unions, the average Saskatchewan resident could be considered to be in the 'middle of the road.' The provincial mean score on the index is 2.52 (standard deviation $=.781$ ), very close to the midpoint of the scale; these results make sense given the diversity of opinion seen on the three scale items.

Our analysis includes all of the socio-economic characteristics mentioned in the pertinent literature. Additionally, due to the traditional rural/urban split in Saskatchewan politics, we added a variable to control for the size of the population of a respondent's community. Given social unionism's insistence on working towards the good of all members of the community, we also controlled for employment status to test the attitudes towards unions of those who are not in the workforce, and therefore not directly affected by collective bargaining or the absence of collective bargaining. Since differences in attitudes may reflect different workplace environments, we distinguish between white-collar workers and blue-collar workers as well as respondents who work in the public sector and respondents who work in the private sector.

Table 2: Predictors of Unions Attitudes in Saskatchewan, 2011

\begin{tabular}{|c|c|c|c|c|}
\hline & $\begin{array}{c}\text { Sympathies } \\
\text { during strike }\end{array}$ & $\begin{array}{l}\text { Unions needed to } \\
\text { protect employees } \\
\text { b (Standard Error) }\end{array}$ & $\begin{array}{l}\text { Unions ask for } \\
\text { too much }\end{array}$ & $\begin{array}{c}\text { Support for } \\
\text { unions index } \\
\text { b (Standard Error) }\end{array}$ \\
\hline Age & $-0.001 \quad(.002)$ & $-0.002 \quad(.002)$ & $-0.005 c \quad(.002)$ & $-0.003 \quad(.002)$ \\
\hline Income & $-0.005 \quad(.009)$ & $-0.029 b \quad(.011)$ & $0.008 \quad(.012)$ & $-0.009 \quad(.008)$ \\
\hline Education & $0.019 \quad(.13)$ & $0.015 \quad(0.17)$ & $0.051 b \quad(.018)$ & $0.031 b \quad(.013)$ \\
\hline Female & $0.094 \quad(.051)$ & $0.059 \quad(.063)$ & $-0.030 \quad(.069)$ & $0.040 \quad(.049)$ \\
\hline Size of Community & $0.034 \quad(.027)$ & $-0.024 \quad(.034)$ & $-0.001 \quad(.037)$ & $-0.007 \quad(.026)$ \\
\hline Employed & $-0.221 a \quad(.067)$ & $-0.318 a \quad(.085)$ & $-0.533 a \quad(.092)$ & $-0.343 a \quad(.065)$ \\
\hline Public Sector & $0.017 \quad(.076)$ & $0.066 \quad(.096)$ & $0.177 \quad(.105)$ & $-0.070 \quad(.074)$ \\
\hline Union Member & $0.436 a \quad(.077)$ & $0.783 a \quad(.096)$ & $0.568 \mathrm{a} \quad(.105)$ & $0.565 a \quad(.074)$ \\
\hline Union Household & $0.179 b \quad(.064)$ & $0.268 a \quad(.081)$ & $0.202 c \quad(.088)$ & $0.195 b \quad(.062)$ \\
\hline NDP Partisan & $0.565 a \quad(.058)$ & $0.711 \mathrm{a} \quad(.074)$ & $0.818 \mathrm{a} \quad(.080)$ & $0.675 a \quad(.057)$ \\
\hline White collar & $0.018 \quad(.063)$ & $-0.156 c \quad(.079)$ & $0.042 \quad(.086)$ & $-.052 \quad(.061)$ \\
\hline Constant & $2.172 \mathrm{a} \quad(.165)$ & $2.936 a \quad(.204)$ & $2.044 a \quad(.225)$ & $2.413 a \quad(.158)$ \\
\hline Adjusted $\mathrm{R}^{2}$ & .197 & .207 & .213 & .256 \\
\hline
\end{tabular}

Notes: all significant coefficients are bolded and $a: p \leq .001, b: p \leq .01, c: p \leq .05$

Source: Saskatchewan Election Study (2011) 
Table 2 outlines the results of a multivariate analysis. We present unstandardized coefficients to provide an indication of the relative importance of our independent variables. The larger the difference between the coefficient and the standard error, the greater the impact of that variable on the respondents' answers measuring the three types of union attitudes and their position on the support for unions index. Further, we have bolded the coefficients that are statistically significant to allow the reader to easily discern which variables are significantly correlated with union attitudes.

First, it is important examine the impact of socio-demographic variables that are not directly connected to a respondent's workplace such as age, income, education, gender, and size of community. The results suggest that these variables have a relatively modest impact on public attitudes towards unions in Saskatchewan. Those with higher incomes are less likely to agree that unions are needed to protect employees and their wages while younger residents tend to believe that unions ask for 'too much'. Having a higher education inclines respondents to disagree with the statement that unions ask for 'too much' and prompts greater overall support for unions.

However, the much stronger impacts are found with variables more directly related to one's employment status such being employed versus not being in the workforce, employment in the private versus the public sector, union membership, living in a union household, and being in a white collar occupation. Not surprisingly, being a union member and, to a lesser extent, living with a union member create more pro-union attitudes across all three questions and higher scores on the 'support for unions' index. On the other hand, being a white-collar worker compared to all others in the sample (blue-collar workers and not being in the workforce) has no impact on union attitudes with the small exception that white collar workers are less likely than others to believe that unions are needed to protect employee's wages and working conditions. The substantive results are not altered if we use blue-collar as the dummy variable (blue-collar=1, all others=0). Similarly, working in the public sector has no impact on respondents' attitudes towards unions.

Our most intriguing finding is that Saskatchewan residents who are currently employed have more negative attitudes towards unions than those who report not being in the workforce (i.e., individuals who are retired, unemployed, full-time students, or caring for family members full-time). On all individual questions as well as the index, being employed produces a relatively large negative impact on attitudes toward unions. This finding may appear counter-intuitive since only those in the work force can enjoy direct protection from unions. On the other hand, retired persons, students and others who are out of the work force are likely to feel economically vulnerable. To the degree that unions are seen to be fighting for an adequate social safety net and government programs that aid the economically insecure, they may be deemed worthy of support by this group in society.

Looking at the large difference between the coefficients and the standard errors, we can see NDP partisanship is a particularly strong predictor of union attitudes. It is striking that NDP partisans have noticeably more positive attitudes towards unions than union members themselves or those who live with union members. This finding suggests that attitudes towards unions are influenced more by ideological factors (i.e., one's commitment to the NDP) than a person's structural position in the economy as a member of a union, living with someone who is a member of a union, or not being in the workforce.

Overall, to summarize, the picture concerning attitudes towards unions in Saskatchewan is nuanced. On a general level, the public appears to feel that union demands can be excessive, but also feels that unions are important institutions for protecting workers' rights and ensuring appropriate working conditions and wages. Further, a significant portion of the public said their sympathies are generally with the workers in the case of a strike. When we perform a multivariate analysis, we find that union members, those who live in union households, NDP partisans, the highly educated, and those not in the workforce are the most likely to have pro-union attitudes. 


\section{Implications of Findings: Social Unionism, the Non-Employed, \& Public Relations}

Despite the success of the conservative Saskatchewan Party in the 2011 provincial election after passing controversial labour legislation, public opinion in Saskatchewan is not uniformly for or against unions. There is an overriding suspicion amongst the public that unions 'ask for too much', which implies that unions may be seen as being too self-interested and acquisitive. However, there is also moderate public sympathy for workers on strike and a strong feeling amongst the public that unions are important institutions that protect employee's wages and promote good working conditions for workers.

These findings have clear implications for literature on Canadian social unionism. It has been underappreciated how Canadian social unionism, which stresses the well-being of all people in society (not just union members), is a good public relations frame to increase the popularity of the union movement. To maximize public support, the Canadian union movement may see advantages to framing its communications with the public around how unions work to improve the lives all community members, including those workers who are not in unions and those who are outside of the workforce. While unions may be tempted to focus how new labour legislation affects their members' interests, a more strategic position may be to take a broader outlook in their opposition to labour legislation proposed by pro-business, conservative governments by framing such legislation as harmful to all of society. In this case, Canadian unions would be best served to adopt a social unionism frame on how such legislation hurts workers in all sectors and how it negatively impacts the most vulnerable within the community. In this way, unions would be wise to strive to be seen as defending the well being of the entire community and not simply the interests of their own members.

Likewise, during negotiations and strikes, unions seeking to appeal to public sympathies might consider framing their demands as being about more than 'just money'. Rather, unions could stress how a just outcome for their workers will improve the well being of their entire community. An example of this approach is seen in Saskatchewan, where the Saskatchewan Union of Nurses has argued that improving the working conditions of nurses will retain the medical professionals in Saskatchewan needed to care for the province's aging population. In this way, the union points out how the interests of its members intersect with the interests of the entire community.

One interesting theoretical question that arises out our findings is the extent to which the 'community' targeted by Canadian social unionist practices includes business. Legitimate questions may be raised about if social unionism is a class-based type of unionism seeking to exclusively represent the interests of the working class. Ross, the preeminent Canadian theorist of social unionism, states that social unionism 'entails a commitment to the interests of the broader working class community' and sees business as being excluded from the community that union activity seeks to benefit (2011: 80). On the other hand, it is possible for Canadian social unionism to define 'community' as an all-encompassing concept that includes business. Union activity could be seen as being able to benefit all segments of society and be in the enlightened self-interest of business. Our findings appear to be more in line with the later interpretation. From a public relations standpoint, speaking about the community as a whole as opposed to just appealing to the working class would be more likely to increase public support for unions. However, more research would need to be to done to confirm that public opinion reacts more favourably to language of 'community' as opposed to language pointing to the 'working class'.

Another implication of our findings for the literature on Canadian social unionism is that unions have a base of support among those who are not currently employed. Canadian social 
unionism's advocacy of defending the interests of and working with the broader community outside of the labour movement takes advantage of this potential opportunity. To increase its overall popularity with the public, the labour movement may want to articulate the position that it is not just defending working people but speaking to the issues that affect all community members, including those outside of the work force who may be in economically insecure positions. Following a social unionism orientation, there may be room for Canadian unions to build both formal and informal alliances with community members who are unemployed, students, retired, or full-time caregivers. In order to do so, unions could advance causes and issues that are of importance to people both inside and outside of the labour movement (e.g., good health care, enhanced retirement security, accessible post-secondary education). It is possible that fruitful associations between unions and groups representing retirees, students, and the unemployed could develop. At the same time, the advertising that unions embark upon could be targeted more towards those outside of the workforce. This targeting could involve using advertising mediums that aim at these socio-demographic groups as well as using images of retirees, full-time caregivers or students in union advertising as opposed to always using images of workers. A concerted effort to reach out to these socio-demographic groups could cultivate a more favourable public relations environment for unions as they struggle against conservative and pro-business governments.

In Canada, there has been considerable debate around the electoral strategy of labour unions (Savage, 2012). Some unions, such as the Canadian Autoworkers, have disaffiliated from the NDP and advocated 'strategic voting' among their members. In the Canadian context, strategic voting means providing 'one time' support to the centrist Liberal party in electoral districts where it has a better chance of defeating conservative candidates than the NDP. Specific to Saskatchewan, Smith (2011) has argued that the provincial labour movement should disaffiliate from the NDP because the party did not fundamentally challenge neo-liberal economic restructuring when it formed government during the 1990s and early 2000s. He argues that a provincial labour movement should decide whether or not to support a political party and which political party to support prior to each election. On the other hand, many 'partisan' Canadian unions (such as the United Food \& Commercial Workers) have maintained their formal affiliation with the NDP and continue to work towards electing NDP candidates in all ridings. As noted above, the partisan unions' long-term and formalized alliance with a social democratic political party is usually seen as being consistent with Canadian social unionist practices. In terms of Saskatchewan, McGrane (2014) argues that the provincial NDP governments of the 1990s and early 2000s did not abandon their social democratic principles and adopted several policies that defied neo-liberal orthodoxy. As mentioned above, debates about the effectiveness of alliances between social democratic parties and unions are common throughout the world (Pillay, 2013).

While our dataset does not allow us to make conclusions about the extent to which the NDP in Saskatchewan contests neo-liberal economic restructuring, it does reveal an interesting finding concerning the public relations advantages that are potentially accrued through a formal alliance between the labour movement and a social democratic party. Indeed, the data from Saskatchewan lend support to Canadian social unionism's advocacy of long-term affiliations with social democratic political parties. Since NDP partisanship is strongly correlated to favourable feelings towards unions, it is possible having more people identify as a NDP partisan could lead to a friendlier public opinion environment for labour. In this way, the activity of the NDP helps to create a basin of support for unions within Saskatchewan public opinion. In the Saskatchewan case, there appears to be a mutually beneficial relationship where the NDP benefits from union support at election time and the labour movement benefits from the NDP's interaction with its partisans that creates positive attitudes towards unions within the public. At the same time, through a long-term affiliation with a 
social democratic party like the NDP unions can legislatively address issues of concern to the entire community such as better healthcare. Undoubtedly, debate over the Canadian labour movement's electoral strategy will continue and it is possible that NDP partisans' positive attitudes towards unions would endure in the absence of a formal and long-term affiliation between the provincial labour movement and the party. However, the extent to which there are public relations advantages for unions of a long-term affiliation with the NDP should be part of discussions concerning the appropriate electoral strategy for unions in Canada.

Governments and business interests can also draw public relations lessons from our findings. When negotiating with unions, businesses and governments would be well served to focus their public relations campaigns on how they are offering a fair settlement and how the union is simply asking for too much. The more that businesses and governments frame unions as a self-interested 'special interest group', the more unsympathetic the public may be to their cause. Further, businesses and governments that are promoting labour legislation that may be perceived as being detrimental to the labour movement benefit by focusing their public relations strategy on the employed and those with lower levels of education. In practical terms, this means pro-business governments display good public relations framing when they are clear that their legislation supports 'hard working people' and focus their advertising in places where those with lower educational demographics are likely to see it. In order to counter-act these public relations strategies, unions must be aware that governments and business will try to frame the issue as 'unions being too greedy' and introduce the counter-frame of 'unions benefiting everyone'.

\section{Conclusion}

As governments around the world continue to restructure their labour policies and embark on austerity bargaining with public sector unions, the public saliency of labour issues will continue to grow. Given this, the lack of academic research examining public attitudes towards unions and the public relations of the labour movement is unfortunate. If unions are to participate in these public debates in an effective fashion, they must pay increased attention to their public relations strategies.

Using the case of Saskatchewan, this article suggests that social unionism is not just an imperative for social justice and a method for union mobilization; it is also appears to be a good public relations strategy. Further, since those outside of the workforce are found to be supportive of the labour movement, our research suggests that unions would be wise to find ways to reach out these socio-demographic groups and be conscious of cultivating their support when faced with public relations challenges. Social unionism, with its insistence on the well being of the entire community and building alliances with groups outside of the labour movement, is a model that is positioned to take advantage of this opportunity. As many unions around the world are facing similar public relations dilemmas caused by the election of conservative governments who are undermining their historic gains, the research agenda that this paper launches is an ambitious one that can be pursued by labour scholars in other jurisdictions. 


\section{METHODOLOGICAL APPENDIX}

The University of Saskatchewan's Social Sciences Research Laboratories (SSRL) conducted the 2011 Saskatchewan Election Study (SKES). Deployed as a telephone survey using WinCATI software, 1,099 Saskatchewan residents, 18 years of age and older, were administered a 15-minute survey on political attitudes and behaviours in the province from November 8, 2011 to November 21,2011 . Results of the survey, which generated a response rate of $23.6 \%$, are generalizable to the Saskatchewan population (18 years of age and older) $+/-2.95 \%$ at the $95 \%$ confidence interval (19 times out of 20). Data are weighted according to age, gender, and region of residence.

In the multivariate analysis (OLS regression), the dependent variables are as follows. Respondents were asked to rate their agreement on a four-point scale (1-Strongly agree, 2-Somewhat agree, 3-Somewhat disagree, 4--Strongly disagree) with the statement: 'All things considered, unions in Saskatchewan generally ask for too much.' The scale was reversed for the next question. Respondents were asked to rate their agreement on a four-point scale (1-Strongly disagree, 2-Somewhat disagree, 3-Somewhat agree, 4-Strongly agree) with the statement that 'Strong unions are needed to protect employees' working conditions and wages.' Further, respondents were asked: "When you hear of a strike, are your sympathies typically '1-Always Against the Union', '2-Usually Against the Union', '3-Usually for the Union', or '4-Always for the Union'?" (The second question was replicated from the 2010 British Election Study, while the third question was replicated from the Australian module of the 1995 International Social Survey). The three questions were combined to create an index ranging from 1.0 ('anti-union' attitudes) to 4.0 ('pro-union' attitudes) (Crohbach's alpha $=.802)$. The index was constructed using mean scores, with missing values excluded.

The multivariate analysis includes a number of control variables. Our analyses include controls for age (an interval variable, measured in years), education (measured in ordinal categories), income (measured in ordinal categories), gender (female $=1$, male $=0$ ), union membership (union member $=1$, all others $=0$ ), union household (union member in household $=1$, all others $=0$ ), public sector employment (work in public sector $=1$, all others $=0$ ), size of community $(1=$ rural, $2=$ cities with populations between 10,000 and 40,000 since there are no cities in Saskatchewan with populations between 40,000 and 200,000, 3 = Regina or Saskatoon which have populations over 200,000), self-reported NDP partisan (NDP partisan $=1$, all others $=0$ ), and white collar ( white collar $=1$, blue collar and not employed $=0$ ). The typology of white collar and blue collar was taken from O'Farell (1999) who argues that the term 'blue-collar' denotes workers that engage in 'manual labour' such as 'Protective services; precision, productions, craft, and repair; operations, fabricators, and laborers; farming, forestry and fishing' (700). All occupations that fell outside of this definition of 'blue collar' were coded as 'white collar'. Teachers and nurse were coded as white collar while all students, retirees, and the unemployed were coded as 'not employed'. 


\section{REFERENCES}

Albo, G. (2002) 'Neoliberalism, the State, and the Left: A Canadian Perspective,' Monthly Review. 54: 46-55.

Angus Reid Strategies (2007) Canadians See Unions as Essential, but Have Little Support For Strikes. Toronto: Angus Reid Strategies.

Angus Reid Strategies (2008) Canadians Support Unions, But Many Think They Are Too Political. Toronto: Angus Reid Strategies.

Archer, J. (1980) Saskatchewan: A History. Saskatoon: Western Producer Books.

Benford, R. and Snow, D. (2000) 'Framing Processes and Social Movements: An Overview and Assessment,' Annual Review of Sociology. 26 (4): 611-639.

Bibby, R. (2002) Canadians and Unions: A National Reading at the Beginning of the New Century. Report prepared for Work Research Foundation, Mississauga, Ontario.

Canadian Labour Congress (2003) Canadians Talk About Unions. Ottawa: Canadian Labour Congress.

Cilek, E. (2014) 'Circulation of social unionism movement concept as a case of Intellectual SouthSouth and North-South Dialogue,' Joint Session, XV111, ISA World Congress of Sociology. 16 July, 2014.

Entman, R.M. (1993) 'Framing: Toward a clarification of a fractured paradigm,' Journal of Communication. 43 (1): 51-58.

Environics Institute for Survey Research (2011) Focus Canada 2011: Final Report. Kingston: Queen's University.

Evans, B. (2012) 'The New Democratic Party in the Era of Neoliberalism,' in Ross, S. and Savage, L. (eds.) Rethinking the Politics of Labour in Canada. Halifax: Fernwood Publishing.

Freeman, R.B, and Medoff, J.L. (1984) What Do Unions Do? New York: Basic Books.

Freeman, G. and Moser, H.R. (2010) 'An Empirical Analysis of the Public's Attitudes toward Labor Union,' National Social Science Journal. 34 (1): 41-60.

Hallahan, K. (1991) 'Seven Models of Framing: Implications for Public Relations,' Journal of Public Relations Research. 11 (2): 205-242.

Hrynyshyn, D. and Ross, S. (2010) 'Canadian Autoworkers, the Climate Crisis and the Contradictions of Social Unionism,' Labor Studies Journal. 36 (1): 5-36. 
Jansen, H. and Young, L. (2009) 'Solidarity Forever? The NDP, Organized Labour, and the Changing Face of Party Finance in Canada,' Canadian Journal of Political Science. 42 (3): 57 678.

Jones, J. (2010) U.S. Approval of Labor Unions Remains Near Record Low. New York: Gallup. [Online] Available at http://www.gallup.com/poll/142007/Americans-Approval-Labor-Unions -Remains-Near-Record-Low.aspx, [Accessed: 10 August, 2012].

Kampur, P. and Murray, G. (2006) 'Innovation in Canadian Unions: Patterns, Causes, and Consequences,' In Kampur, C. and Schenk, C. (eds.) Paths to Union Renewal: Canadian Experiences. Peterborough: Broadview Press.

Krahn, H. and Lowe, G. (1984) 'Public Attitudes Towards Unions: Some Canadian Evidence,' Journal of Labor Research. 5 (1): 149-164.

Laycock, D. (2014) 'Conceptual Foundations of Continuity and Change in NDP Ideology,' in Laycock, D. and Erickson, L. (eds.) Reviving Social Democracy: The Near Death and Surprising Rise of the Federal NDP. Vancouver: UBC Press.

Leger Marketing (2003) What Are Canada's 'Labourers' Really Thinking This Labour Day, Research report prepared for the National Post and Global News for their State of the Unions series.

Lindsay, R. (1987) Co-operation and Conflict: The CCF and the Canadian Congress of Labour in Saskatchewan, 1944-1956. Unpublished Masters' Thesis, Department of History, University of Saskatchewan.

Lipset, S. (1950) Agrarian Socialism: CCF in Saskatchewan. Garden City: Anchor Books.

McCuaig, I., Sass, B., and Stobbe, M. (1991) 'Labour Pains: The Birth of New Industrial Relations Order in Saskatchewan, 1982-1991,' in Biggs, L. and Stobbe, M. (eds.) Devine Rule in Saskatchewan: A Decade of Hope and Hardship. Saskatoon: Fifth House Publishers, pp. 149175.

McGrane, D. (2008) 'Which Third Way? A Comparison of the Romanow and Calvert NDP Governments from 1991 to 2007,' in Leeson, H. (ed.) Saskatchewan Politics: Crowding the Centre. Regina: University of Regina Press.

McGrane, D. (2014) Remaining Loyal: Social Democracy in Quebec and Saskatchewan. Montreal: McGill-Queen's University Press.

Moody, K. (1997) Workers in a Lean World. London: Verso.

Morissette, R., Schellenberg, G. and Johnson, A. (2005) 'Diverging trends in unionization,' Perspectives April 2005. Statistics Canada Catalogue no. 75-001-xie, pp. 5-12.

O'Farrell, B. (1999) 'Women in Blue Collar and Related Occupations at the End of the Millennium,' The Quarterly Review of Economics and Finance. 39 (4): 699-722. 
Pew Research Center (2010) Favorable Ratings of Labor Unions Fall Sharply. Washington, DC: The Pew Research Center.

Pillay, D. (2013) 'Between Social Movement and Political Unionism: COSATU and Democratic Politics in South Africa,' Rethinking Development and Inequality. 2: 10-27.

Robinson, I. (1993) 'Economistic Unionism in Crisis: The Origins, Consequences and Prospects of Canada-U.S. Labour Movement Character Divergence,' in Jenson, J. and Mahon, R. (eds.) The Challenge of Restructuring: North American Labor Movements Respond. Philadelphia: Temple University Press.

Robinson, I. (2000) 'Neo-liberal restructuring and U.S. Unions: Towards Social Movement Unionism,' Critical Sociology. 26 (2): 109-138.

Ross, S. (2007) 'The Varieties of Social Unionism: Towards a Framework for Comparison,' Just Labour. 11 (1): 16-34.

Ross, S. (2008) 'Social Unionism and Membership Participation: What Role for Union Democracy?,' Studies in Political Economy. 81: 129-157.

Ross, S. (2011) 'Social Unionism in Hard Times: Union-Community Coalition Politics in the CAW Windsor’s Manufacturing Matters Campaign,' Labour/Le Travail. 68: 79-115.

Ross, S. (2012) 'Business Unionism and Social Unionism in Theory and Practice,' in Ross, S. and Savage, L. (eds.) Rethinking the Politics of Labour in Canada. Halifax: Fernwood Publishing.

Savage, L. and Soron, D. (2011) 'Organized Labor, Nuclear Power, and Environmental Justice: a comparative analysis of the Canadian and U.S. labor movements,' Labor Studies Journal. 36 (1): 37-57.

Savage, L. (2012) 'Organized Labour and the Politics of Strategic Voting,' in Ross, S. and Savage, L. (eds.) Rethinking the Politics of Labour in Canada. Halifax: Fernwood Publishing.

Saad, L. (2009) Labor Unions See Sharp Slide in U.S. Public Support. New York: Gallup. [Online] Available at http://www.gallup.com/poll/122744/Labor-Unions-Sharp-Slide-Public-Support. aspx\#1, [Accessed: 9 August 2012].

Seidman, G. (2011) 'Social movement unionism: From Description to Exhortation,' South African Review of Sociology. 42 (3): 94-102.

Schmitt, J. and Mitukiewicz A. (2012) 'Politics Matter: Changes in Unionization Rates in Rich Countries, 1960-2010,' Industrial Relations Journal. 43 (3): 260-280.

Smith, C. (2011) "The 'New Normal' in Saskatchewan: Neoliberalism and the Challenge to Workers' Rights," in McGrane, D. (ed.) New Directions in Saskatchewan Public Policy. Regina: Canadian Plains Research Center Press. 
Snyder, G. (1997) 'Social Justice for Workers,' in Glor, E. (ed.) Policy Innovation in the Saskatchewan Public Sector, 1971-1982. North York: Captus Press.

Suzuki, A. (2013) Cross-National Comparisons of Social Movement Unionism: Diversities of Labour Movement Revitalization in Japan, Korea, and the United States. Bern: Peter Lang.

Swimmer, G. and Bartkiw, T. (2006) 'Provincial Policies Concerning Collective Bargaining,' in Dunn, C. (ed.) Provinces: Canadian Provincial Politics, Second Edition. Toronto: University of Toronto Press.

Uppal, S. (2010) 'Unionization 2010,' Perspectives: October 2010. Statistics Canada Catalogue no. 75-001-x, pp. 18-27.

Visser, J. and Checchi, D. (2009) 'Inequality and the Labour Market: Unions,' in Salverda, W., Nolvan, B., and Smeeding, T. (eds.) The Oxford Handbook of Economic Inequality. Oxford: Oxford University Press.

Warren, J and Carlisle, K. (2005) On the Side of the People: A History of Labour in Saskatchewan. Regina: Coteau Books.

Webster, E. (2008) 'Recasting Labor Studies in the Twenty-First Century,' Labor Studies Journal. 33 (3): 249-254.

Wesley, J. (2011) Code Politics: Campaigns and Cultures on the Canadian Prairies. Vancouver: UBC Press.

\section{BIOGRAPHICAL NOTE}

DAVID MCGRANE, is Associate Professor of Political Studies at St. Thomas More College at the University of Saskatchewan, in Saskatoon, Saskatchewan, Canada.

[Email: david.mcgrane@usask.ca]

LOLEEN BERDAHL is Associate Professor of Political Studies at the University of Saskatchewan in Saskatoon, Saskatchewan, Canada.

[Email: Ioleen.berdahl@usask.ca] 